\title{
Polymorphisms at the ligand binding site of the vitamin D receptor gene and osteomalacia ${ }^{1}$
}

\author{
Duygu Gezen Ak ${ }^{\mathrm{a}}$, Hakkı Kahraman ${ }^{\mathrm{b}}$, Erdinç Dursun ${ }^{\mathrm{a}}$, Belgin Süsleyici Duman ${ }^{\mathrm{c}}$, Nevin Erensoy ${ }^{\mathrm{d}}$, \\ Faruk Alagöl ${ }^{\mathrm{e}}$, Refik Tanakol ${ }^{\mathrm{e}}$ and Selma Yılmazer ${ }^{\mathrm{a}, *}$ \\ ${ }^{a}$ Department of Medical Biology, Cerrahpasa Faculty of Medicine, Istanbul University, Turkey \\ ${ }^{\mathrm{b}}$ Department of Internal Medicine, Faculty of Medicine, University of 19 Mayls, Turkey \\ ${ }^{\mathrm{c}}$ Department of Medical Biology, Faculty of Medicine, University of Kadir Has, Turkey \\ ${ }^{\mathrm{d}}$ Institute for Experimental Medicine, Istanbul University, Turkey \\ e Department of Endocrinology and Metabolism, Faculty of Medicine, Istanbul University, Turkey
}

\begin{abstract}
Vitamin D receptor (VDR) gene polymorphisms have been suggested as possible determinants of bone mineral density (BMD) and calcium metabolism. In this study, our aim was to determine whether there is an association between VDR gene polymorphism and osteomalacia or not. We determined ApaI and TaqI polymorphisms in the vitamin D receptor gene in 24 patients with osteomalacia and 25 age-matched healthy controls. Serum calcium, phosphorus, ALP, PTH, 25OHD levels were also examined. We used PCR and RFLP methods to test for an association between osteomalacia and polymorphisms within, intron 8 and exon 9 of the VDR gene. When the control and patients were compared for their ApaI and TaqI genotypes there was no relationship between VDR gene allelic polymorphisms and osteomalacia. Whereas a nearly significant difference for A allele was found in the allellic distribution of the patients $(p=0.08)$. Also no association between biochemical data and VDR gene polymorphisms was observed.
\end{abstract}

Keywords: Vitamin D, osteomalacia, vitamin D receptor gene, ApaI, TaqI

\section{Introduction}

1.25-dihydroxyvitamin $\mathrm{D}_{3}\left(1.25(\mathrm{OH})_{2} \mathrm{D}_{3}\right)$ is involved in biological actions such as calcium homeostasis, bone mineralization, cell proliferation and cell differentiation [16,17,23]. Vitamin D deficiency usually occurs in the lack of dietary intake, abnormal metabolism of vitamin D or inadequate synthesis of vitamin $\mathrm{D}$ in the skin. In addition, it may result from intestinal malabsorption, chronic renal disease or very rarely, from liver failure. Such kind of insufficiency of

\footnotetext{
${ }^{1}$ This study is supported by The Research Fund of Istanbul University.

*Corresponding author: Prof. Dr. Selma Yilmazer, Department of Medical Biology, Cerrahpasa Faculty of Medicine, Istanbul University, Istanbul, Turkey. Tel.: +90 21241430 00/22032; +90 532 27407 15; Fax: +90 21241430 42; E-mail: selmayilmazer@ mynet.com.
}

vitamin D causes mineralization defect of bone matrix rather than frank osteoporosis [21,26,28,31]. Without vitamin $\mathrm{D}$, children develop rickets and adults exacerbate their osteoporosis and develop osteomalacia [18].

The genomic actions of vitamin $\mathrm{D}_{3}$ are mediated through its nuclear receptor, the vitamin $\mathrm{D}$ receptor (VDR), which is a member of the nuclear hormone receptor superfamily [16]. Genetic factors are considered to be major determinants of bone mineral mass. Common polymorphisms in the $3^{\prime}-$ and $5^{\prime}-$ end region of the VDR gene have been suggested as possible determinants of bone mineral mass and, hence, of the risk of osteoporosis. These polymorphisms are identified by the restriction enzymes $\mathrm{BsmI}(\mathrm{BB}, \mathrm{Bb}, \mathrm{bb})$ or alternatively TaqI (TT, Tt, tt) and ApaI (AA, Aa, aa) [5, 26].

At least 22 unique loss of function mutations in the VDR gene have been reported. Single nucleotide changes producing amino acid substitutions in the 
DNA-and ligand-binding domains are predominate mutations. These mutations cause hereditary vitamin $\mathrm{D}$ resistant rickets, a rare autosomal recessive disease resulting from target organ resistance to $1.25(\mathrm{OH})_{2} \mathrm{D}_{3}$ [9].

Osteomalacia is frequently seen in Turkey $[2,4,24$, 27]. The effects of genetic factors in pathogenesis of osteomalacia are not clear. Some individuals are more prone to have features of osteomalacia although they are living in the same habitat and having the same dietary. The only study about this subject could not be able to show any association between VDR gene BsmI polymorphism and osteomalacia [4]. We think that further investigation on the other polymorphisms of the VDR gene is required to determine the effect of these polymorphisms on osteomalacia. In the present study, the effect of VDR gene ApaI and TaqI polymorphisms on osteomalacia was investigated.

\section{Subjects and methods}

\subsection{Subjects}

Twenty-four patients ( 21 female, 3 male; age: 45.16 \pm 13.99 years.) who met the clinical (muscle weakness of the lower extremities, walking difficulties, bone pain worsening by activity), biochemical (low or lownormal serum calcium and phosphorus, low serum 25 hydroxyvitamin D [OHD], increased alkaline phosphatase and PTH levels), and/or radiological (pseudofractures) criteria of osteomalacia were included in this study. Patients are clinically diagnosed at Istanbul University, Faculty of Medicine, Department of Endocrinology and Metabolism, Bone Diseases Unit. Patients with osteomalacia due to causes other than vitamin D depletion such as hypophosphatemia and renal osteodistrophy were excluded from the study. Twentyfive age matched healthy controls ( 22 female, 3 male; age: $41.08 \pm 13.35$ years.) had no history of diseases affecting bone metobolism. None of the subjects in the two groups were taking medicine affecting bone metabolism. Patients and healthy controls were not classified according to their calcium intake, which was determined to be above $800 \mathrm{mg}$ per day, assessed by asking about 3-day calcium intake [6]. The study was approved by the Ethics Commitee of Research Fund of Istanbul University. Informed consents were obtained from all subjects.

\subsection{Biochemical analysis}

Fasting blood samples were collected in the same season (fall) for the measurement of calcium (Ca), phosphorus (P), alkaline phosphatase (ALP), parathyroid hormone (PTH) and 25-hydroxyvitamin D (25OHD). Serum Ca, P and ALP were measured by Roche Diagnostics (Mannheim, Germany) Modular System. Serum intact PTH was measured with DSL8000 Active Intact PTH IRMA kit from Diagnostic Systems Laboratories, Inc (Webster, Texas, USA), with intra-and interassay coefficients of variations of 2.8 and $3.6 \%$, respectively. Serum 25OHD was measured by Diasorin 25OHD RIA kit (Stillwater, Minnesota, USA) with intra-and interassay coefficients of variations of 10.4 and $9.4 \%$, respectively.

\subsection{Genotype assignment}

DNA was extracted from $10 \mathrm{ml}$ of $\mathrm{K}_{3}$ EDTA (Ethylenediaminetetraacetic acid) treated peripheral blood by the salting out method. A 740 base pair fragment which includes intron 8 and exon 9 of the vitamin $\mathrm{D}$ receptor gene in chromosome 12 was amplified by the polymerase chain reaction (PCR) with forward (5'CAGAGCATGGACAGGGAGCAAG-3') and reverse (5'-GCAACTCCTCATGGCTGAGGTCTCA-3') [12] primers to detect Apa I and Taq I sites. PCR products were generated in a $25 \mu \mathrm{l}$ reaction volume containing $100 \mathrm{ng}$ of genomic DNA, 1x PCR buffer, $1.8 \mathrm{mM}$ $\mathrm{MgCl}_{2}, 200 \mu \mathrm{M}$ of $\mathrm{dNTP}, 10 \mathrm{pmol} / \mu \mathrm{l}$ of each primer and $0.5 \mathrm{U}$ of Taq DNA polymerase. PCR was performed as follows: incubation for $5 \mathrm{~min}$. at $94^{\circ} \mathrm{C}, 10$ cycles of incubation for $20 \mathrm{~s}$ at $94^{\circ} \mathrm{C}, 40 \mathrm{~s}$ at $64^{\circ} \mathrm{C}$, and $1 \mathrm{~min}$. at $72^{\circ} \mathrm{C}, 25$ cycles of incubation for $20 \mathrm{~s}$ at $94^{\circ} \mathrm{C}, 40 \mathrm{~s}$ at $62^{\circ} \mathrm{C}$, and $1 \mathrm{~min}$. at $72^{\circ} \mathrm{C}$, followed by an extension step of $6 \mathrm{~min}$. at $72^{\circ} \mathrm{C}$. To determine the presence of Apa I and Taq I restriction sites, we performed Restriction Fragment Length Polymorphism (RFLP). Five $\mu$ l PCR products were digested with $2 \mu$ l of DNase, RNase free water and $2 \mathrm{U}$ of Apa I enzyme at $37^{\circ} \mathrm{C}$ and $2 \mathrm{U}$ of Taq I enzyme at $66^{\circ} \mathrm{C}$, separately. Digestion products were analyzed in $1.5 \%$ agarose gel stained with ethidium bromide (Applichem, Darmstadt, Germany). DNA fragments were visualized by ultraviolet illumination and fragment size estimated by comparison to $50 \mathrm{bp}$ ladder run on the same gel. The presence of ApaI restriction site causes spliting of the PCR product into two bands, $529 \mathrm{bp}$ and $211 \mathrm{bp}$, respectively, designated as $a$. If ApaI restriction site is not present in the corresponding sequence remained a $740 \mathrm{bp}$ single 


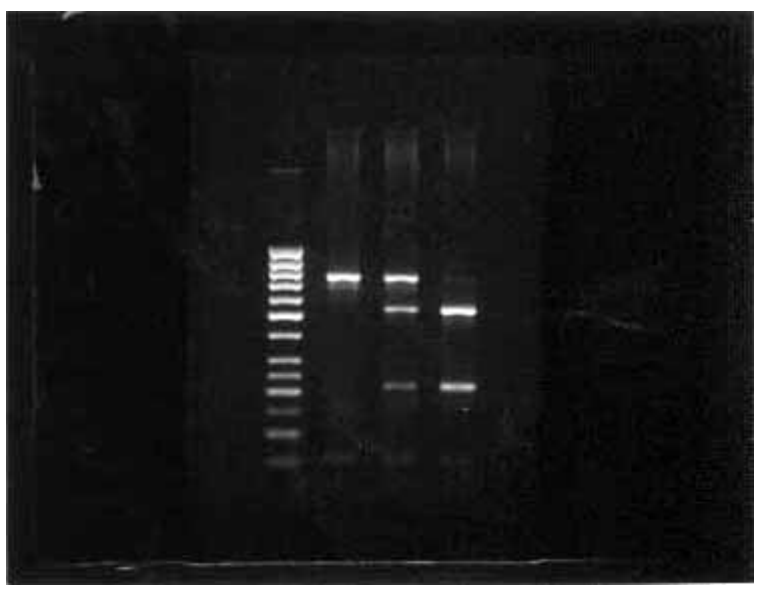

Fig. 1. RFLP results of ApaI enzyme. Lane 1, Gene RulerTM 50 bp DNA Ladder. Lane 2, AA genotype (740 bp, homozygous). Lane 3, Aa genotype ( 740 bp, 529 bp and 211 bp, heterozygous). Lane 4, aa genotype (529 bp and $211 \mathrm{bp}$, homozygous) (bp=base pairs).

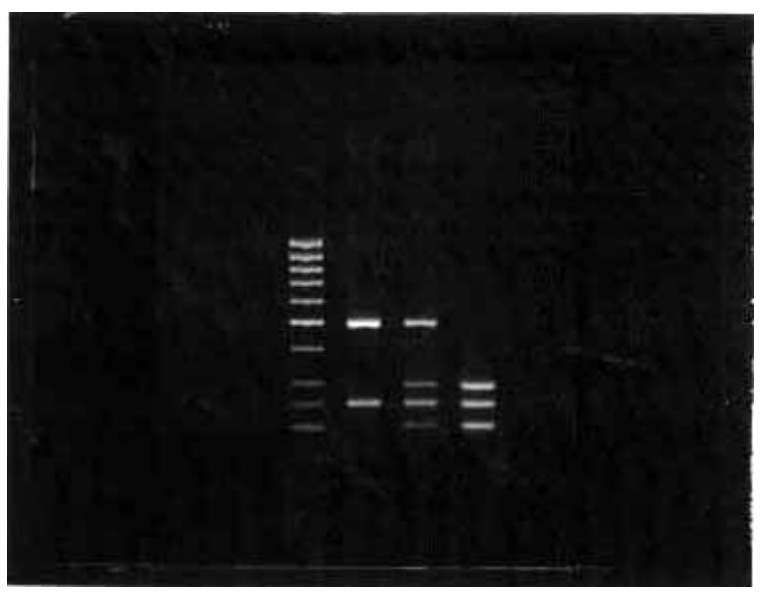

Fig. 2. RFLP results of TaqI enzyme. Lane 1, Gene RulerTM 50 bp DNA Ladder. Lane 2, TT genotype (493 bp and 247 bp, homozygous). Lane 3, Tt genotype (493 bp, $291 \mathrm{bp}, 247 \mathrm{bp}$ and 202 bp, heterozygous). Lane 4, tt genotype (291 bp, $247 \mathrm{bp}$ and 202 bp, homozygous).

band, designated as A (Fig. 1). The presence of TaqI restriction site causes spliting of the PCR product into three bands, 291 bp, 247 bp and 202 bp respectively, designated as $t$. If RFLP-associated TaqI restriction site is not found in the corresponding sequence were split into two bands, 493 bp and 247 bp respectively, designated as $T$ (Fig. 2).

\subsection{Statistics}

Statistical analysis were performed by UNISTAT 5.0 ${ }^{\circledR}$ software. To compare ALP and PTH levels the nonparametric Mann Whitney U-Wilcoxon Rank Sum $\mathrm{W}$ test was used. Also to determine the distribution of $\mathrm{Ca}, \mathrm{P}, 25 \mathrm{OHD}$ levels and age in groups, t- Test was used. The distribution of biochemical parameters and VDR genotypes by groups were determined by analysis of variance (two-way ANOVA).

\section{Results}

\subsection{Biochemical parameters}

Patients and healthy controls were age matched $(45.16 \pm 13.99$ yrs.; $41.08 \pm 13.35$ years, respectively $p=0.306)$. Serum calcium $(8.57 \pm 0.99 \mathrm{mg} / \mathrm{dl}$ vs. $9.29 \pm 0.53 \mathrm{mg} / \mathrm{dl} p=0.004$; reference range: $8.5-10.5 \mathrm{mg} / \mathrm{dL})$, phosphorus $(3.05 \pm 0.71 \mathrm{mg} / \mathrm{dl} \mathrm{vs}$. $3.69 \pm 0.45 \mathrm{mg} / \mathrm{dl} p=0.001$; reference range: $2.7-$ $4.5 \mathrm{mg} / \mathrm{dL})$ and $25 \mathrm{OHD}(6.90 \pm 5.04 \mathrm{ng} / \mathrm{ml} \mathrm{vs} .16 .30 \pm$ $12.15 p=0.0005$; reference range: $15-56 \mathrm{ng} / \mathrm{ml})$ levels were lower and serum ALP (329.15 \pm 311.97 IU/L vs. $65.33 \pm 15.53 \mathrm{IU} / \mathrm{L} p=0.0004$; reference range: 90-260 U/L) and PTH (225.41 $\pm 170.31 \mathrm{pg} / \mathrm{ml}$ vs. $40.54 \pm 22.36 \mathrm{pg} / \mathrm{dl} p=<0.001$; reference range: $15-$ $65 \mathrm{pg} / \mathrm{ml}$ ) were higher in the patient group than those in the control group (Table 1). These findings were statistically significant.

\subsection{VDR alleles}

After genetic analysis of the VDR gene, we found $50 \%$ genotype AA, $45.8 \%$ genotype Aa, $4.2 \%$ genotype aa and $33.3 \%$ genotype TT, $62.5 \%$ genotype $\mathrm{Tt}, 4.2 \%$ genotype $\mathrm{tt}$ for patients and $28 \%$ genotype AA, $56 \%$ genotype Aa, $16 \%$ genotype aa and $36 \%$ genotype TT, $52 \%$ genotype $\mathrm{Tt}, 12 \%$ genotype $\mathrm{tt}$ for healthy controls. When the control and patients were compared for their Apa I and Taq I genotypes, we observed that the genotype distribution did not differ $(p=0.18 ; p=0.55$ respectively) whereas when the allellic distributions of the patients and controls compared for the ApaI polymorphism a nearly significant difference was found for the A allele as it was slightly increased in the patients $(p=0.08)$ (Table 2$)$. Additionally no association between biochemical data and VDR gene polymorphisms was observed (Tables 3 and 4). 
Table 1

Comparison of biochemical findings with vitamin D receptor (VDR) genotypes in osteomalacia and control groups

\begin{tabular}{|c|c|c|c|c|c|}
\hline \multirow[t]{2}{*}{ Parameters } & \multirow[t]{2}{*}{ Patients } & \multirow[t]{2}{*}{ Controls } & \multicolumn{3}{|c|}{2 way ANOVA } \\
\hline & & & $\mathrm{a}$ & $\mathrm{b}$ & $\mathrm{c}$ \\
\hline${ }^{\mathrm{a}}$ Age (years) & $45.16 \pm 13.99$ & $41.08 \pm 13.35$ & NS & - & - \\
\hline${ }^{\mathrm{a}} \mathrm{Ca}(\mathrm{mg} / \mathrm{dl})$ & $8.57 \pm 0.99$ & $9.29 \pm 0.53$ & $0.004 *$ & NS & NS \\
\hline${ }^{\mathrm{a}} \mathrm{P}(\mathrm{mg} / \mathrm{dl})$ & $3.05 \pm 0.71$ & $3.69 \pm 0.45$ & $0.001^{*}$ & NS & NS \\
\hline${ }^{\mathrm{b}} \mathrm{ALP}(\mathrm{U} / \mathrm{l})$ & $329.15 \pm 311.97$ & $65.33 \pm 15.53$ & $0.0004 *$ & $\mathrm{NS}$ & NS \\
\hline${ }^{\mathrm{a}} 25 \mathrm{OHD}(\mathrm{ng} / \mathrm{ml})$ & $6.90 \pm 5.04$ & $16.30 \pm 12.15$ & $0.0005^{*}$ & NS & NS \\
\hline b PTH (pg/ml) & $225.41 \pm 170.31$ & $40.54 \pm 22.36$ & $<0.001^{*}$ & NS & NS \\
\hline
\end{tabular}

\section{Discussion}

It is suggested that VDR gene and the allelic variations of the 3' end region of this gene have an important role to determine the relation between vitamin $\mathrm{D}$ metabolism and the effects of genetic factors in bone formation $[5,20,26]$.

In 1994 Morrison et al. suggested, in their study over healthy Caucasian twins, that there is a close association between VDR gene polymorphisms and BMD by over 75\% [30] although many studies in several populations have failed to detect a significant association between bone mass and VDR gene alleles [1,7,15,22, 29]. It was suggested that, there is a relationship between $\mathrm{BB}, \mathrm{tt}$, AA polymorphisms of VDR gene and the low BMD. It was found that twins with genotype bbTTaa have $15 \%$ higher BMD than the twins with BbttAA genotype [22].

There were controversial results reported on the effects of VDR genotypes on BMD. The studies which aim to explain this contradiction show that the relationship between BMD and VDR gene polymorphisms occurs in case of low calcium intake $[11,20]$. When premenopausal women with dietary high and low calcium intake were compared, it was found that the amount of calcium taken effects the BMD in individuals with $\mathrm{Bb}$ and BB genotypes, but does not effect individuals with bb genotypes [26]. In addition to this, parallel findings were obtained with the pre-adolescence girls with bb genotypes. Accordingly, there was a significant correlation between dietary calcium levels and BMD gain in $\mathrm{Bb}$ and probably $\mathrm{BB}$ but not in bb. It is suggested that calcium absorbtion decreases in low calcium intake due to of a possible functional error in vitamin $D$ receptors of individuals with BB genotype [11]. Apa I and Taq I polymorphisms are also located in the ligand binding domain of VDR gene as BsmI polymorphism.
Table 2

Allellic distributions of VDR gene ApaI polymorphism

$\begin{array}{lll} & \text { Allele A } & \text { Allele a } \\ \text { Controls } & 28(0.56) & 22(0.44) \\ \text { Patients } & 35(0.73) & 13(0.27)\end{array}$

$p=0.08$. First numbers are the number of patients and controls. The numbers in paranthesis are frequency.

The allelic variation of these polymorphic sites might cause a change in the affinity of VDR to its ligand [14, 20]. It was mentioned that calcium absorption is higher in bbTT genotype which is reported to be related with high BMD than in BBtt genotype and lower in BbttAA genotype which is related to low BMD than in bbTTaa and BbTtAa genotypes [13]. Calcium absorbtion in pre and postmenopausal women with the BAt haplotypes was found to be $11 \%$ and $37 \%$ lower, respectively when compared to that of women with the baT haplotype indicating that the effect of VDR gene variation on calcium absorption may also be modified by age or hormonal status $[8,13]$. However, a recent study reports that the Bat haplotype is associated with high bone density in normal subjects [10].

It is known that the vitamin D resistance is a consequence of mutations in VDR gene [17]. Although it is not clear, whether genetic factors have a role in the pathogenesis of osteomalacia or not, Kahraman et al. suggested that some VDR genotypes are more prone to osteomalacia [4]. VDR polymorphisms might have an effect on the osteomalacia, caused by the lack of vitamin $\mathrm{D}$, as they effect the $\mathrm{Ca}^{+2}$ absorbtion. It is suggested that the $\mathrm{Ca}^{+2}$ absorbtion might be decreased by some polymorphisms in VDR gene, in low $\mathrm{Ca}^{+2}$ intake [11]. Since the major role of vitamin $\mathrm{D}$ and its receptor is to regulate the amount of $\mathrm{Ca}^{+2}$ binding proteins and the expression of $\mathrm{Ca}^{+2}$ channels in cells it is possible that VDR polymorphisms effect the $\mathrm{Ca}^{+2} \mathrm{ab}-$ sorbtion in low vitamin D intake, due to the alterations in the affinity of VDR to its ligand vitamin D [3,25]. 
Table 3

\begin{tabular}{|c|c|c|c|c|c|}
\hline \multicolumn{6}{|c|}{ ApaI genotypes and biochemical findings in osteomalacia patients and controls* } \\
\hline \multirow[t]{2}{*}{ Parameters } & \multicolumn{2}{|c|}{ VDR Genotypes/Patients } & \multicolumn{2}{|c|}{ VDR Genotypes/Controls } & 2 way \\
\hline & AA & $\mathrm{Aa}$ & AA & $\mathrm{Aa}$ & ANOVA P value \\
\hline Age (years) & $41.83 \pm 14.76$ & $49.00 \pm 13.45$ & $38.57 \pm 11.41$ & $41.69 \pm 11.81$ & 0.948 \\
\hline $\mathrm{Ca}(\mathrm{mg} / \mathrm{dl})$ & $8.55 \pm 0.66$ & $8.56 \pm 1.33$ & $9.27 \pm 0.64$ & $9.34 \pm 0.47$ & 0.594 \\
\hline $\mathrm{P}(\mathrm{mg} / \mathrm{dl})$ & $3.15 \pm 0.70$ & $2.94 \pm 0.77$ & $3.74 \pm 0.33$ & $3.66 \pm 0.55$ & 0.508 \\
\hline $\operatorname{ALP}(\mathrm{U} / \mathrm{l})$ & $276.27 \pm 234.11$ & $436.63 \pm 396.53$ & $61.83 \pm 7.88$ & $61.84 \pm 9.13$ & 0.202 \\
\hline $25 \mathrm{OHD}(\mathrm{ng} / \mathrm{ml})$ & $8.45 \pm 6.59$ & $5.44 \pm 2.24$ & $13.41 \pm 10.28$ & $16.36 \pm 9.47$ & 0.16 \\
\hline PTH (pg/ml) & $252.63 \pm 199.47$ & $218.64 \pm 138.39$ & $37.46 \pm 26.44$ & $35.94 \pm 16.36$ & 0.913 \\
\hline \multicolumn{6}{|c|}{ * "aa" genotype $(n<5)$ could not be analyzed with two way ANOVA. } \\
\hline \multicolumn{6}{|c|}{ Table 4} \\
\hline & TaqI genotypes anc & biochemical finding & osteomalacia pati & nts and controls & \\
\hline \multirow[t]{2}{*}{ Parameters } & \multicolumn{2}{|c|}{ VDR Genotypes/Patients } & \multicolumn{2}{|c|}{ VDR Genotypes/Controls } & 2 way \\
\hline & TT & $\mathrm{Tt}$ & TT & $\mathrm{Tt}$ & ANOVA P value \\
\hline Age (years) & $47.13 \pm 13.56$ & $44.33 \pm 15.04$ & $39.67 \pm 15.07$ & $41.58 \pm 13.58$ & 0.978 \\
\hline $\mathrm{Ca}(\mathrm{mg} / \mathrm{dl})$ & $8.26 \pm 1.19$ & $8.79 \pm 0.86$ & $9.47 \pm 0.47$ & $9.12 \pm 0.43$ & 0.248 \\
\hline $\mathrm{P}(\mathrm{mg} / \mathrm{dl})$ & $2.69 \pm 0.67$ & $3.17 \pm 0.65$ & $3.66 \pm 0.43$ & $3.75 \pm 0.50$ & 0.875 \\
\hline $\operatorname{ALP}(\mathrm{U} / \mathrm{l})$ & $431.63 \pm 401.73$ & $260.83 \pm 229.53$ & $65.86 \pm 8.69$ & $64.59 \pm 19.86$ & 0.429 \\
\hline 25OHD (ng/ml) & $5.73 \pm 2.05$ & $7.78 \pm 6.32$ & $14.16 \pm 15.02$ & $18.10 \pm 9.35$ & 0.792 \\
\hline PTH (pg/ml) & $211.22 \pm 162.85$ & $230.66 \pm 188.29$ & $42.27 \pm 26.02$ & $43.19 \pm 21.13$ & 0.519 \\
\hline
\end{tabular}

In our study, the frequency of Apa 1 polymorphism was $50 \%$ for AA; $45.8 \%$ for Aa; $4.2 \%$ for aa in patients and $28 \%$ for AA; $56 \%$ for Aa; $16 \%$ for aa in the healthy controls. The patients with AA genotype were $50 \%$ of the total patient number and when compared to the control group it had a higher ratio, however, this difference is not considered as statistically significant whereas allellic distribution of A allele was found to be slightly increased in the patients and became statistically nearly significant. The frequency of Taq 1 polymorphisms were $33 \%$ for TT; $62.5 \%$ for $\mathrm{Tt} ; 4.2 \%$ for $\mathrm{tt}$ in the patients, whereas $36 \%$ for TT; $52 \%$ for Tt; $12 \%$ for $\mathrm{tt}$ in the healthy controls. There was no statistically significant difference between the genotype distribution of patient and control groups. Kahraman et al. have studied the relationship between osteomalacia and VDR gene Bsm 1 polymorphism and could not be able to determine an association [4]. The association between osteomalacia and VDR gene polymorphisms arise from the relative discussion of BMD and calcium absorbtion results of the other studies. These studies suggested that the AAtt genotype was related to low BMD and low calcium absorbtion $[8,13,22]$. Similarly, it can be suggested that in addition to vitamin D deficiency, also AAtt genotypes which may cause low affinity of VDR to vitamin D may affect the defective calcification of bone in osteomalacia.

In our study, the combined genotypes were considered and it was found that the ratio of AATt genotypes in the patient and control groups were $50 \%$ and $12 \%$, respectively. Although these findings were not statistically significant, the results seem to be parallel with the other studies in terms of AA genotype which is suggested to be related with low BMD and low calcium absorbtion. On the other hand, according to our results, it is not consistent with those studies since tt genotype has been observed in $4.2 \%$ of the patients and $12 \%$ of the healthy controls. In our study, when the biochemichal analyses and the VDR genotypes of the patients were compared, the patients with Aa genotype had higher ALP and lower 25OHD values than patients with AA genotype, even not statistically significant. Likewise, the controls and the patients with TT genotype had higher ALP and lower 25OHD values when compared with the controls and patients with Tt genotype. According to this, individuals with AaTT genotype seemed more prone to osteomalacia. However, only $29.2 \%$ of osteomalacia group had this genotype. In this respect, a significant relation has not been found. Similarly, in a study carried out with postmenopausal Caucasian women it is reported that no relationship was observed between VDR genotypes and ALP, 25OHD, $1.25(\mathrm{OH})_{2} \mathrm{D}_{3}$ and PTH levels [13].

Consequently, in our study a probable but not convincing relationship has been found between the VDR gene polymorphisms and osteomalacia. This situation might have arised because of the insufficient number of samples. Although there is no significant differences between the distribution of the genotypes of the patients and the controls in our study, the higher ratio of the 
TtAA and only AA genotypes of the patients and the finding that nearly significant difference of the A allele in the patients suggest that it should be investigated further by increasing the number of subjects.

\section{Acknowledgments}

This work was supported by the Research Fund of The Istanbul University. Project number: T1221/01112001. We are also greateful for the help of Ömer Uysal, M.Sc., who carried out the statistical analysis of the study.

\section{References}

[1] B.D. Hughes, S.S. Harris and S. Finneran, Calcium absorption on high and low calcium intakes in relation to vitamin D receptor genotypes, J Clin Endocrinol Metab 80(12) (1995), 3657-3661.

[2] F. Alagol, Y. Shihadeh, H. Boztepe, R. Tanakol, S. Yarman, H. Azizlerli and O. Sandalci, Sunlight exposure and vitamin $\mathrm{D}$ deficiency in Turkish women, J Endocrinol Invest 23(3) (2000), 173-177.

[3] F. Bronner, Mechanisms of intestinal calcium absorption, $J$ Cell Biochem 88(2) (2003), 387-393.

[4] H. Kahraman, B. Süsleyici-Duman, F. Alagöl, R. Tanakol and $\mathrm{S}$. Y1lmazer, Lack of association between vitamin $\mathrm{D}$ receptor gene polymorphism (Bsm I) and osteomalacia, J Bone Miner Metab 22 (2004), 39-43.

[5] H.A.P. Pols, A.G. Uitterlinden and J.P.T.M. Van Leeuwen, How about vitamin D polymorphisms, Osteoporos Int 8 (1998), 20-23.

[6] Institute of Medicine. Dietary Reference Intakes for Calcium, Phosphorus, Magnesium, Vitamin D, and Fluoride. Washington, DC: National Academy Press, 1997.

[7] J.E. Looney, H.K. Yoon, M. Fischer, S.M. Farley, J.R. Farley, J.E. Wergedal and D.J. Baylink, Lack of a high prevalence of the bb vitamin D receptor genotype in severely osteoporotic women, J Clin Endocrinol Metab 80(7) (1995), 2158-2162.

[8] J.M. Wishart, M. Horowitz, A.G. Need, F. Scopacasa, H.A. Morris, P.M. Clifton and B.E. Nordin, Relations between calcium intake, calcitriol, polymorphisms of the vitamin D receptor gene, and calcium absorption in premenopausal women, Am J Clin Nutr 65 (1997), 798-802.

[9] J. Zmuda, J. Cauley and R. Ferrell, Vitamin D receptor gene variants and osteoporosis, Epidemiologic Reviews 22(2) (2000), 203-217.

[10] K. Douroudis, K. Tarassi, G. Ioannidis, F. Giannakopoulos, P. Moutsatsou, N. Thalassinos and C. Papasteriades, Association of vitamin $\mathrm{D}$ receptor gene polymorphisms with bone mineral density in postmenopausal women of Hellenic origin, Maturitas 45 (2003), 191-197.

[11] K. Kohama, J. Uemasu, H. Kawasaki, E. Nanba and A. Tokumoto, Association between vitamin D receptor gene polymorphisims and renal osteodystrophy in patients on maintenance hemodialysis, Yonago Acta Medica 43 (2000), 27-38.
[12] L. Fountas, P. Moutsatsou, I. Kastanis, N. Tamouridis, M. Tzanela, M. Anapliotou and C.E. Sekeris, The contribution of Vitamin D Receptor gene polymorphisms in osteoporosis and familial osteoporosis, Osteoporos Int 10 (1999), 392-398.

[13] L. Gennari, L. Becherini, A. Falchetti, L. Masi, F. Massart and M.L. Brandi, Genetics of osteoporosis: role of steroid hormon receptor gene polymorphisms, J Steroid Biochem Mol Biol 81 (2002), 11-24.

[14] L. Gennari, L. Becherini, L. Masi, S. Gonnelli, C. Cepollaro, S. Martini, R. Mansani and M.L. Brandi, Vitamin D Receptor Genotypes and Intestinal Calcium Absorption In Postmenopausal Women, Calcif Tissue Int 61 (1997), 460-463.

[15] L.A. Houston, S.F.A. Grant, D.M. Reld and S.H. Ralston, Vitamin D Receptor alleles, bone mineral density and osteoporotic fracture: studies in a UK population, Bone 17(3) (1995), 320.

[16] L.L. Issa, G.M. Leong and J.A. Eisman, Molecular mechanism of vitamin D receptor action, Inflamm res 47 (1997), 451-475.

[17] M. Thomas and M.B. Demay, Vitamin D deficiency and disorders of vitamin D metabolism, Endocrinol Metab Clin North Am 29 (2000), 611-627.

[18] M.F. Holick, Noncalcemic actions of 1,25-dihydroxyvitamin $\mathrm{D}_{3}$ and clinical applications, Bone 17(2) (1995), 107-111.

[19] N.A.J. Morrison, C. Qi, A. Tokita, P.J. Kelly, L. Crofts, T.V. Nguyen, P.N. Sambrook and J.A. Eisman, Prediction of bone density from vitamin D receptor alleles, Nature 367 (1994), 284-287.

[20] N.A. Morrison, R. Yeoman, P.J. Kelly and J.A. Eisman, Contribution of trans-acting factor alleles to normal physiological variability: vitamin D receptor gene polymorphisms and circulating osteocalcin, Proc Natl Acad Sci USA 89 (1992), 6665-6669.

[21] P. Chandrasoma and C.R. Taylor, Concise Pathology, 1st ed., Appleton and Lange, California, USA, 1991.

[22] Q. Cai, J.S. Chandler, R.H. Wasserman, R. Kumar and J.T. Penniston, Vitamin D and adaptation to dietary calcium and phosphate deficiencies increase intestinal plasma membrane calcium pump gene expression, Proc Natl Acad Sci USA 90 (1993), 1345-1349.

[23] R. Bouillon, G. Carmeliet, E. Daci, S. Segaert and A. Verstuyf, Vitamin D metabolism and action, Osteoporos Int 8 (1998), 13-19.

[24] R. Guzel, E. Kozanoglu, F. Guler-Uysal, S. Soyupak and T. Sarpel, Vitamin D status and bone mineral density of veiled and unveiled Turkish women, $J$ Womens Health Gend Based Med 10(8) (2001), 765-770.

[25] R.M. Evans, The steroid and thyroid hormone receptor superfamily, Science 240 (1988), 889-895.

[26] S. Ferrari, J.P. Bonjour and R. Rizzoli, The vitamin D receptor gene and calcium metabolism, Trends Endocrinol Metab 9/7 (1998), 259-263.

[27] S. Gullu, M.F. Erdogan, A.R. Uysal, N. Baskal, A.N. Kamel and G. Erdogan, A potential risk for osteomalacia due to sociocultural lifestyle in Turkish women, Endocr J 45(5) (1998), 675-678.

[28] S. Kato, K. Sekine, T. Matsumoto and T. Yoshizawa, Molecular genetics of vitamin $\mathrm{D}$ receptor acting in bone, $J$ Bone Miner Metab 16 (1998), 65-71.

[29] S.K. Lim, Y.S. Park, J.M. Park, Y.D. E.J. Song, Lee, K.R. Kim, H.C. Lee and K.B. Huh, Lack of Association between vitamin D receptor genotypes and osteoporosis in Koreans, $J$ Clin Endocrinol Metab 80(12) (1995), 3677-3681.

[30] T.S. Hansen, B. Abrahamsen, F.L. Henriksen, A.P. Hermann, L.B. Jensen, M. Horder and J. Gram, Vitamin D receptor 
alleles do not predict bone mineral density or bone loss in Danish premenopausal women, Bone 22(5) (1998), 571-575.

[31] W.M. Kohrt, D.B. Snead, E. Slatopolsky and S.J. Birge, Add- itive effects of weight-bearing exercise and estrogen on bone mineral density in older women, J Bone Miner Res 10(9) (1995), 1310-1322. 


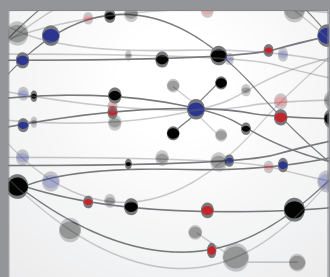

The Scientific World Journal
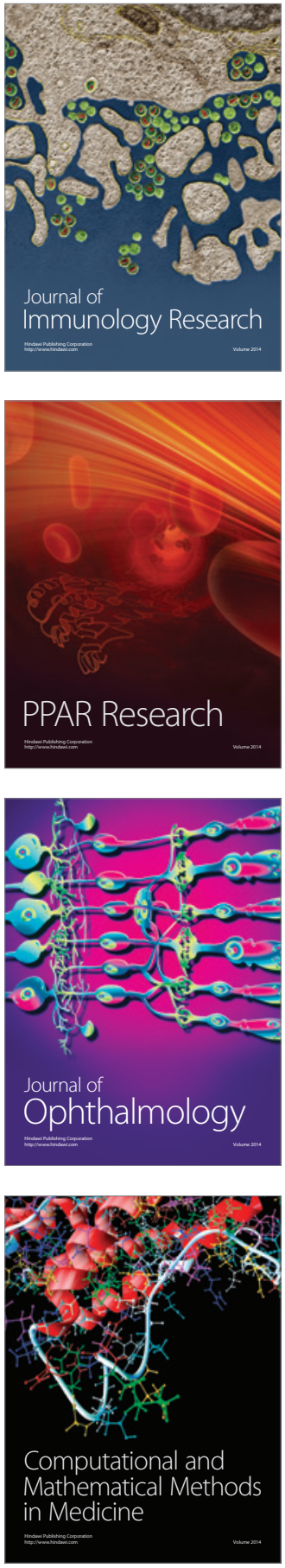

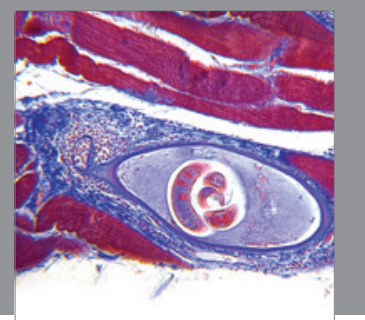

Gastroenterology

Research and Practice
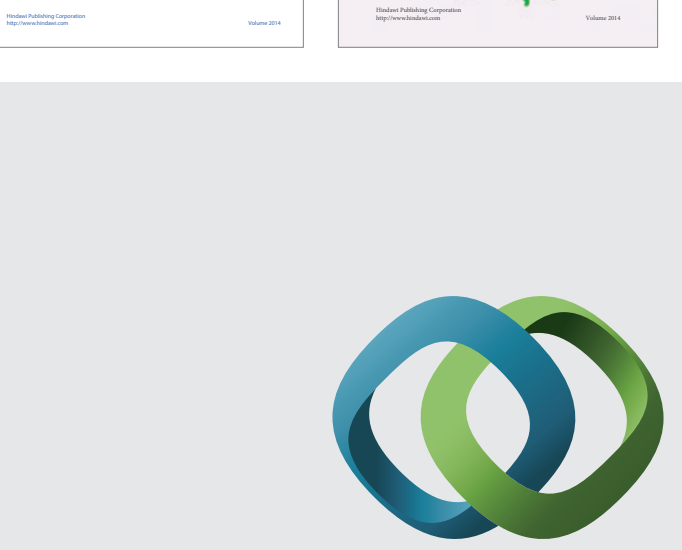

\section{Hindawi}

Submit your manuscripts at

http://www.hindawi.com
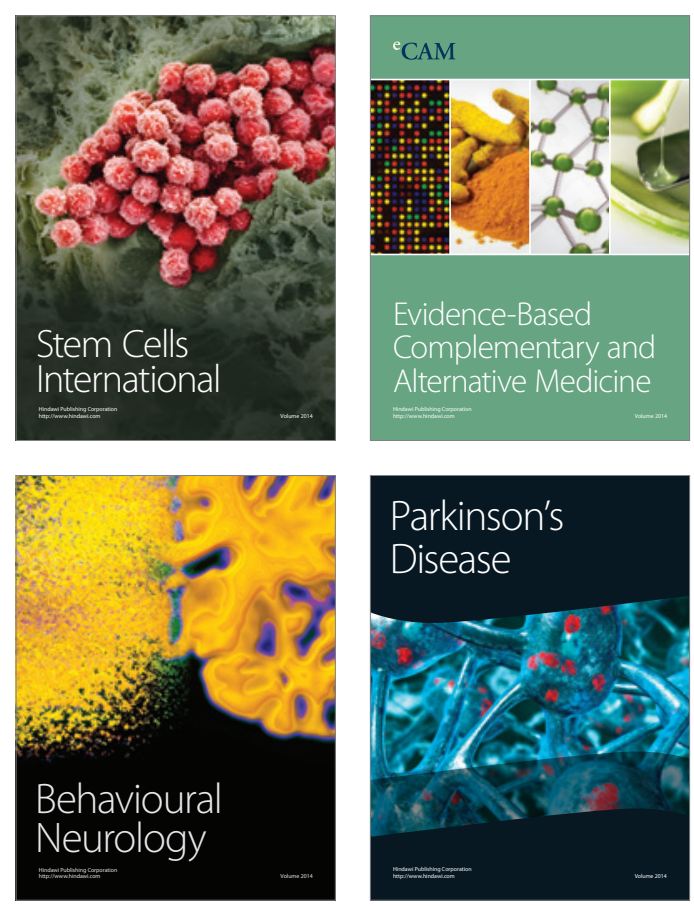

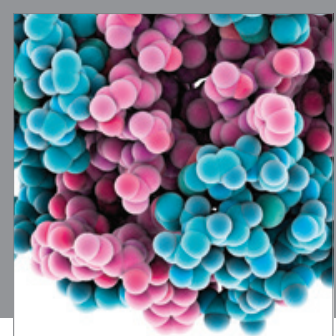

Journal of
Diabetes Research

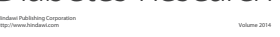

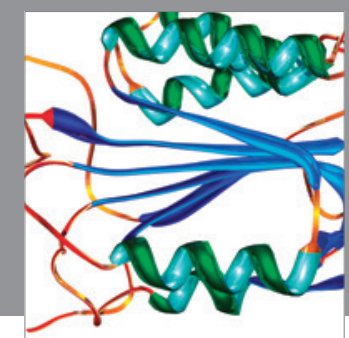

Disease Markers
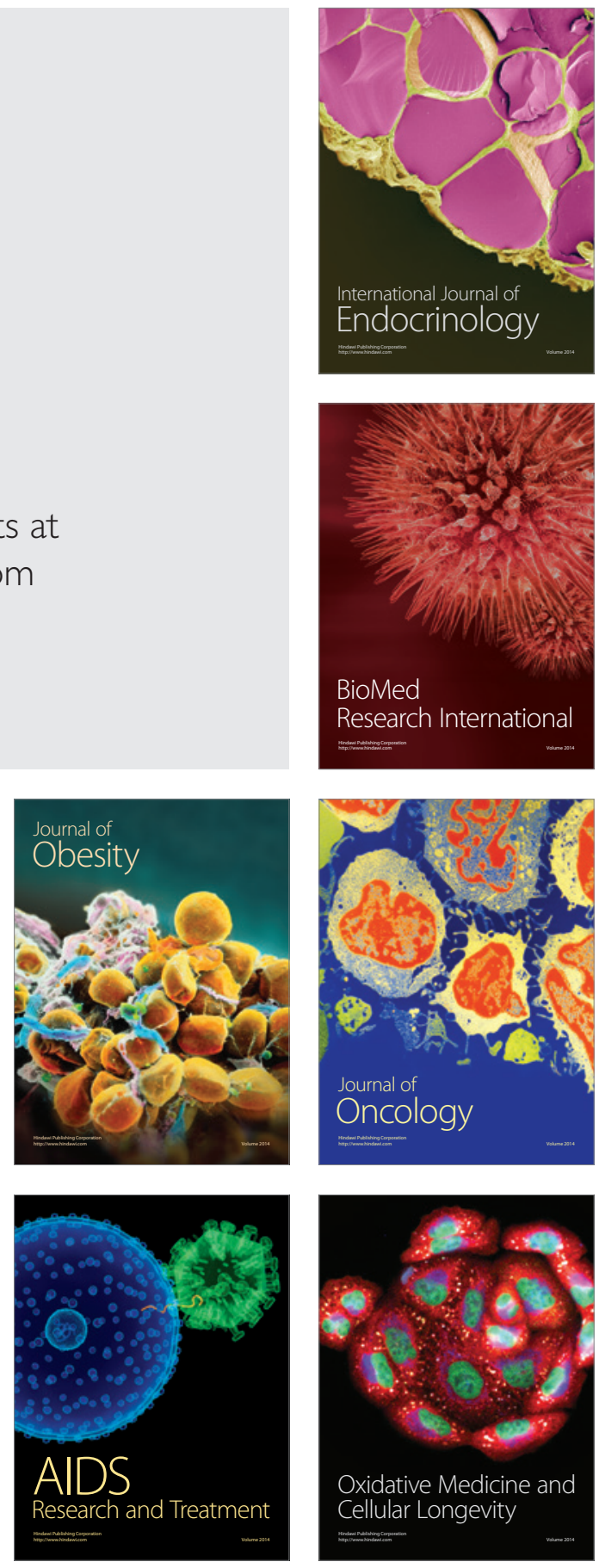